\title{
TRADISI MATRILINEAL DALAM TJOERITO PARASAIAN ME'SALEH
}

\author{
Ka'bati
}

Universitas Islam Negeri (UIN) Imam Bonjol, kabati77@gmail.com

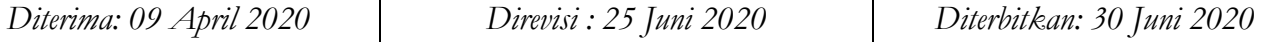

\begin{abstract}
This article discusses the neglect of matrilineal tradition by Pariaman society during the colonial era (18461922), based on a study of autobiography written by Me' Saleh gala Datoe' Oerang Kajo Basa. The book entitled Tjoerito Parasaian Me' Saleh is a family historical note of successful trader in Pariaman. The society in Pariaman is known as heterogeneous in terms of ethnicity, cultures, and religion, in contrast to darek. society that is known as homogeneous in the mentioned fields. The heterogeneity of the Pariaman society then forms a social relational pattern and it is a different form compared to the darek society. The autobiography illustrates that the cultural characteristics of Pariaman society in the beginning was formed by their interaction with foreign people from Aceh, Nias, Bugis, India, China, Madura, Arab, and European countries. Since then they became an open minded people and easy to adapt with new influences. This condition resulted some matrilineal tradition applied in darek was not implemented and obeyed in rantau.
\end{abstract}

Keywords: family history, autobiography $M e^{\prime}$ Saleh, matrilineal system

\section{Abstrak}

Artikel ini membicarakan tentang pengabaian tradisi matrilineal oleh masyarakat Pariaman pada masa kolonial antara tahun 1846-1922 bersadarkan hasil telaahan naskah otobiografi karangan Me' Saleh gala Datoe' Oerang Kajo Basa yang berjudul Tjoerito Parasaian Me' Saleh ini sebuah catatan sejarah keluarga pedagang sukses di Pariaman. Masyarakat Pariaman dalam sejarah dikenal heterogen dari segi etnis, budaya dan agama, berbeda dengan darek yang dianggap homogen dan asli.Heterogenitas masyarakat Pariaman ini kemudian membentuk pola relasi sosial yang berbeda dengan masyarakat di dataran tinggi atau darek Minangkabau. Otobiografi ini menceritakan corak budaya masyarakat di Pariaman terbentuk karena persentuhan mereka dengan orang asing seperti Aceh, Nias, Bugis, India, Cina, Madura, Arab dan Eropa, sehingga kelompok masyarakat Pariaman menjai masyarakat yang terbuka dan mudah beradaptasi. Kondisi ini membuat beberapa bentuk dari tradisi matrilineal yang berlaku di darek justru tidak dipatuhi di rantau.

Kata Kunci: Sejarah Keluarga, Otobiografi Me’ Saleh, Sistem Matrilineal

\section{Latar Belakang}

Tjoerito Parasaian Me' Saleh adalah sebuah otobiografi yang ditulis oleh seorang laki-laki bernama Me' Saleh gala Datoe' Oerang Kajo Basa, pedagang besar yang menetap di Pariaman pada rentang awal abad ke XIX ${ }^{1}$. Buku ini kemudian menjadi catatan penting bagi pengkaji sejarah, terutama mereka yang fokus meneliti tentang masyarakat di

${ }^{1}$ Latif,S.M, (1933), Tjoerito Parasaian Me' Saleh Gala Datoe' Oerang Kajo Basa, Bandoeng. Hal, II 
Hindia Belanda pada masa Kolonial. Tsuyoshi Kato telah menjadikan buku ini sebagai bahan rujukan utama dalam tulisannya berjudul Rantau Pariaman: Dunia saudagar Pesisir Minangkabau Abad XIX. ${ }^{2}$ Sejarawan Mestika Zed juga menjadikan buku ini sebagai sumber utama penulisan buku berjudul Saudagar Pariaman Menerjang Ombak Membangun Maskapai. ${ }^{3}$ Selain dua tulisan Kato dan Zed, ditemukan juga artikel lain yang membahas buku otobiografi ini seperti ditulis Undri ${ }^{4}$ juga Efrianto ${ }^{5}$.

Digunakannya ontobiografi sebagai rujukan kajian ilmiah dalam dunia pengetahuan membuktikan kemampuan bahasa sebagai media yang dapat merepresentasikan peristiwa yang terjadi pada masa lalu.Para pendukung pascastrukturalisme mengenalnya dengan istilah linguistic tum, yang menurut Purwanto, merupakan sebuah pernyataan bahwa bahasa dalam bentuk budaya dan intelektual merupakan media pertukaran bagi hubungan antar kekuatan dan konstitutor dari kebenaran tentang masa lalu. ${ }^{6}$ Bahasa sebagai teks dan laki-laki sebagai pemilik teks akan terhubung dalam sebuah konteks dan memunculkan paradigma yang khas laki-laki. Dalam konteks pemahaman seperti inilah kemudian penulisan artikel ini dilakukan dengan membaca kembali catatancatatan Me'Saleh sebagai representasi

2 Nagazumi, Akira. (Ed), Indonesia Dalam Kajian Sarjana Jepang, Jakarta: Yayasan Obor Indonesia. Hal 77

3 Zed, Mestika, (2017), Saudagar Pariaman Menerjang Ombak Membangun Maskapai, Jakarta:LP3ES.

4 Undri, (2019), Narasi Gempa dalam Otobiografi Moehammad Saleh Datoek Rangkayo Basa, Jurnal Sejarah.Vol 2 (2). hal 50-65

5 A. Efrianto, (2016), Jejak Peradaban Masa Lalu di Kota Pariaman, Jurnal Penelitian Sejarah dan Budaya, Vol 2 No 1, Juni 2016. h 390-415.

${ }^{6}$ Purwanto. Bambang, (2001), Historisisme \& Kesadaran Dekonstruktif: Kajian Kritis Terhadap Historiografi Indonesiasentris. Jurnal Humaniora: Volume XIII No 1/2001 pengetahuan antar teks yang memuat pemahaman dan pemaknaannya akan peristiwa sejarah yang terjadi dalam kesehariannya, terutama berkaitan dengan cara pandang serta sikapnya terhadap sistem matrilineal Minangkabau.

Seperti yang dinyatakan dalam bukunya, bahwa tulisan itu dibuat untuk mengenang perjalanan hidup serta pembelajaran serta teladan bagi anak keturunannya kelak.Dengan tegas Me'Saleh menuliskan bahwa buku itu merupakan sumber pengetahuan bagi anak keturunannya agar mereka tahu dengan aturan hidup nenek moyang mereka. ${ }^{7}$ Menarik pada bagian pembuka buku dia tidak menyebut peruntukan buku itu buat anak kemenakan, seperti kelaziman yang diucapkan ninik mamak, penghulu atau seorang laki-laki Minangkabau yang sadar akan nasab ibu dan berperan tidak hanya sebagai ayah tetapi juga sebagai mamak di kaum ibunya.

Matrilineal merupakan sistem sosial yang berlaku di kalangan etnis Minangkabau, atau bisa disebut sebagai warisan nenek moyang dimana Me'saleh dan anak-anaknya kemudian tumbuh. Sebuah sistem yang menyandarkan nasab (garis keturunan) mereka pada ibu.Sistem ini dijalankan sebagai sebuah tatanan kehidupan bersama oleh etnis mayoritas di Sumatera Barat, sampai hari ini.

Sistem matrilineal sebagai adat kebiasaan (adat yang diadatkan) dalam masyarakat Minangkabau meliputi tradisi pernikahan dan pengasuhan anak, peristiwa kematian, hak waris juga pembagian harta pusaka. Semua ketentuan adat ini disepakati bersama melalui diktum yang populer: Adat Basandi Syara' Syarak Basandi Kitabullah (ABS-SBK).Tulisan ini mencoba melihat bagaimana sistem matrilineal ini hadir dalam keseharian Me'saleh dan bagaimana seorang

${ }^{7}$ Op.cit, hal. 3 
Me'saleh merepresentasikannya dalam teks yang ditulisnya.

\section{Sistem Matrilineal di Minangkabau}

Terbentuknya sistem matrilineal di dalam masyarakat Minangkabau berlangsung melalui proses panjang dan diwarnai aneka konflik sosial. Konflik tersebut diantaranya terlihat pada akhir abad ke 19 yang akhirnya melahirkan konsensus Bukit Marapalam: Adat Basandi Sara' Sara' Basandi Kitabullah. Sidi Gazalba dan beberapa peneliti lain seperti Schrieke, ${ }^{8}$ dan Dobbin ${ }^{9}$ mengatakan bahwa konflik ini sebenarnya hanya hal biasa yang lebih cenderung berakar pada kepentingan kolonial, politik dan ekonomi lalu dibesarbesarkan oleh para peneliti Barat ${ }^{10}$.

Namun pada penelitian-penelitian berikutnya ditemui pula bahwa perseteruan antara adat dan agama ini memang menjadi kentara di seputar tradisi matrilineal dan Islam yang cenderung patrilineal. Hal ini bisa dilihat dari sejarah munculnya perang Paderi dan kehadiran ulama-ulama Paderi yang hendak melakukan pemurnian Islam di bawah pengaruh ideologi wahabi yang muncul pada abad ke 18 di Timur Tengah. Perselisihan tersebut, sebagaimana diakui Alaidin Koto, kemudian berlanjut antara kaum tua (ulama tradisional) dan kaum muda bahkan masih terasa sampai hari ini $^{11}$. Navis juga menyatakan hal yang sama, dimana pertentangan yang berkaitan dengan sistem matrilinial itu terus

\footnotetext{
${ }^{8}$ Schrieke,B.J.O, (1973), Pergolakan Agama diSumatera Barat,Jakarta. Bratara.

${ }^{9}$ Dobbin, Christine, (2008), Gejolak Ekonomi, Kebangkitan Islam dan Gerakan Padri Minangkabau 1784-1847. Jakarta: Komunitas Bambu. Hal 185-225

${ }^{10}$ Gazalba Sidi, (1996), Konflik dan Penyesuaian Antara Adat, Agama dan Pengaruh Barat, Padang: Kertas Kerja Seminar Islam di Minangkabau. h 6.

11 Koto, Alaiddin, (1996), Pemikiran politik Persatuan Tarbiyah Islamiyah, Pekanbaru: Susqa Press. h $9-25$
}

muncul dan mengalami pergesekan secara dinamis ${ }^{12}$.

Sistem matrilineal memberi keleluasaan pada kaum laki-laki di Minangkabau untuk bebas dari tanggungjawab sebagai seorang suami di rumah istrinya. Keleluasaan inilah yang kemudian menjadi alasan bagi kebanyakan kaum laki-laki kala itu untuk menghabiskan harinya dengan berjudi atau menyabung ayam di arena publik tanpa harus risau memikirkan kehidupan materi bagi keluarganya. Dekadensi dan demoralisasi meluas, inilah kemudian yang menurut Muhamad Radjab menjadi pemicu awal munculnya gerakan Paderi (1803-1838) ${ }^{13}$. Radjab juga mengkritik keras tradisi matrilineal yang menurutnya memberi pengaruh buruk terhadap mental anak-anak, memperkuat otoritas mamak (saudara laki-laki ibu) dan memperlemah peran ayah ${ }^{14}$. Tentu saja pandangan Radjab ini tidak sepenuhnya benar, terutama kalau kita mengacu pada konsep ideal sebagaimana terbaca dalam Undang - Undang Minangkabau (UUM) ${ }^{15}$. Tetapi, adanya dinamika hukum adat memungkinkan bagi masyarakat untuk membenarkan tindakan demoralisasi ini. Bahkan dinamika hukum adat ini melahirkan paradigma ganda terutama antara golongan yang berseberangan: Golongan adat dan golongan agama.

Dilema antara hukum adat dan agama serta hukum formal yang berlaku di Indonesia disederhanakan oleh Yaswirman sebagai sebuah kenyataan sehari-hari yang sama sekali tidak mengganggu. Dalam analisisnya tentang

12 Navis,A.A, (1999), yang Berjalan Sepanjang Jalan, Jakarta: Grasindo. hal 94-95

13 Radjab Muhamad, (1964), Perang Paderi di Sumatera Barat (1803-1838), Djakarta: P.N. Balai Pustaka. h 9

${ }^{14}$ Radjab Muhamad, (1969), Sistem Kekerabatan di Minangkabau, Padang: Center for Minangkabau Studies Press. h 31

15 Zuriati, (2007), Undang-Undang Minangkabau Dalam Perspektif Ulama Sufi, Padang: FS Universitas Andalas. H 118-130 
sejarah, karakteristik dan prospek hukum adat dan Islam dalam masyarakat matrilineal Minangkabau Yaswirman menjelaskan pertentangan ini akan bisa diselesaikan karena adanya nilai-nilai universal dalam masingmasing tradisi yang berlaku ${ }^{16}$.

Perdebatan soal sistem matrilineal terus berlangsung bahkan sampai kemudian memasuki wilayah mitos. Sistem adat Minangkabau ini kemudian menjadi mitos dan dimitoskan, dimana Umar Yunus membahasakannya sebagai suatu pengukuhan (myth of concern) dan sekaligus juga sebagai upaya pembebasan (myth of freedom) ${ }^{17}$. Masyarakat Minangkabau, menurut Junus terus-menerus berada dalam 'pertentangan' antara keinginan untuk bebas dari mitos sistem sosial mereka (adat matrilineal) dan juga untuk mempertahankannya. ${ }^{18}$

Wilayah Minangkabau secara geografis dan sosio kultural meliputi wilayah, rantau pesisir dan darek. Pembagian wilayah ini berdasarkan tambo adat mengacu pada riake nan badabua, sabilia pasia nan panjang ${ }^{19}$. Minangkabau darek meliputi wilayah Luhak Agam, Luhak Tanah Datar dan Luhak 50 Koto sementara minang rantau meliputi daerah di pesisir barat seperti Tiku, Pariaman, Pasaman, Pesisir Selatan, sampai ke Bangkinang, Kampar dan Rokan.

Pariaman pada masa kolonial menjadi daerah sentral perdagangan untuk wilayah pesisir pantai barat Sumatera.Masyarakat Pariaman dalam sejarah dikenal heterogen dari segi etnis, budaya dan agama, berbeda dengan darek yang dianggap homogen dan asli.Homogenitas masyarakat Pariaman ini kemudian melahirkan pola relasi sosial yang

16 Yaswirman, (2006), Hukum Keluarga Adat dan Islam, Padang:Andalas University Press

17 Junus Umar, (1981), Mitos dan Komunikasi, Jakarta: Sinar Harapan. h 84-85

18 Ibid. H. 86

${ }^{19}$ Yaswirman, op.cit. h 101 berbeda antara masyarakat di pesisir pantai dan masyarakat di dataran tinggi.

Perbedaan itu tergambar dari buku otobiografi Tjoerito Parasaian Me'saleh. Di samping itu ada proses heterogenitas masyarakat di Pariaman terbentuk karena persentuhan mereka dengan orang asing seperti Aceh, Nias, Bugis, India, Cina, Madura, Arab dan Eropa.Dengan begitu mereka menjadi masyarakat yang terbuka dan mudah beradaptasi. Berdasarkan telaahan terhadap naskah otobiografi Me' Saleh gala Datoe' Oerang Kajo Basa berjudul Tjoerito Parasaian Me' Saleh, ditemukan beberapa keunikan sistem sosial dan relasi kuasa dalam masyarakat Pariaman yang merupakan daerah rantau Minangkabau yang bertentangan dengan tradisi matrilineal yang berlaku di darek.

Buku ini merupakan sebuah catatan sejarah keluargaan pembisnis bernama Me' Saleh. Awalnya ditulis dalam Bahasa Melayu dengan menggunakan huruf Arab (Arab Melayu) pada tahun 1915. Tiga tahun sebelum si pengarang wafat ${ }^{20}$. Rentang tahun 18461922 yang menjadi latar peristiwa dalam kisah ini dicatat dalam sejarah sebagai tahun penuh polemik, antara sistem adat (matrilineal) dan agama (Islam) yang cenderung patrilineal. ${ }^{21}$

Kisahkan dalam buku tersebut dimulai dari penggambaran bagaimana orang tua lakilaki Me'Saleh yang bernama Peto Radjo membangun bisnisnya namun kemudian jatuh bangkrut karena terlena oleh kesenangan serta memperturutkan adat-istiadat setempat seperti menyabung ayam, memelihara banyak budak, meminum tuak dan mengisap ganja dan menikah banyak (poligami) ${ }^{22}$. Setelah ayahnya yang saudagar besar itu bangkrut tanpa (tidak

\footnotetext{
${ }^{20}$ Latif, S.M, (1933), Tjoerito Parasaian Me' Saleh versi ke dua, Bandung. hal ii

${ }^{21}$ Schrieke, B.J.O, (1973), Pergolakan Agama di Sumatera Barat. Jakarta: Bratara. hal 94

${ }^{22}$ Latif, op.cit. hal 13
} 
ada diceritakan) meninggalkan warisan harta apapun kecuali nasehat-nasehat, Me'Saleh (seperti juga jalan yang ditempuh ayahnya) memulai sendiri bisnisnya dari nol, dari usaha berjualan bada atau ikan kering sampai kemudian dia bisa dipercaya sebagai pengemudi kapal dagang dan berjualan antar pulau. Dia juga memiliki banyak gudang penyimpanan barang, tanah dan rumah yang luas. Dalam buku itu sesungguhnya yang lebih banyak dikemukakannya adalah soal parasaian (kesusahan) hidup serta hubungan batinnya yang sangat dekat dengan sang ayah. Sebuah nilai yang ingin dia wariskan kepada anak cucunya.Alasannya bercerita soal parasaian adalah agar anak cucunya kelak tahu menghargai keringat dan usaha sendiri. Intinya, buku ini memang semacam catatan hidup otobiografi, bukan secara khusus membahas soal tradisi matrilineal, namun bagaimanapun, karena hidup di daerah rantau Minangkabau serta percaturan budaya yang heterogen mau tidak mau dalam buku ini juga turut tergambar bagaimana budaya masyarakat berlaku kala itu.

Dalam perkembangannya, buku otobiografi Tjoerito Parasaian Me' Saleh telah mengalami beberapa tahapan penyaduran dari bentuk aslinya. Pertama edisi bahasa Melayu yang terbit tahun 1933. Merupakan karangan S.M Latif dan dilengkapi dengan gambar, peta dan lukisan. Judul yang dibubuhkan pada halaman depan adalah Tjoerito Parasaian Me'Saleh Gala Datoea' Oerang Kajo Basa.

Buku Tjoerito Parasaian Me'Saleh Gala Datoea' Oerang Kajo Basaini salah satunya tersimpan sebagai koleksi Yayasan Dokumentasi dan Informasi Kebudayaan Minangkabau (YDIM) dengan nomor 1326. Di sampulnya tertulis bahwa Prof. Dr. C. Snouck Hurgronje dan Prof Dr. Ph.S. Van Ronkel sangat mengapresiasi buku ini. Di halaman depan ditulis: Prof. Dr. C. Snouck Hurgronje en Prof Dr. Ph.S. Van Ronkel, lieten zich in zeer waardeerende zin over dit werl wit. Bandoeng-1933.

Sepertinya upaya penulisan ulang buku ini, selain dilatarbelakangi oleh semangat kekeluargaan dan kesadaran pentingnya sebuah sejarah keluarga, juga karena dorongan pihak kolonial. Pada tahun yang sama juga sangat banyak ditemukan tulisan-tulisan Snouck Hurgronje sebagai sebuah upaya pendokumentasian kehidupan masyarakat di nusantara. Soenjono Dardjowidjojo dalam sebuah artikelnya berjudul Kolonialisme dan Pengembangan Bahasa Nasional mengatakan bahwa pada tahun awal tahun 1890, Kern dan Hurgronje sedang giat menjalankan projek yang disebut oleh Robert van Niel sebagai upaya menciptaan suatu rasa tertarik pada diri sendiri di antara orang-orang Indonesia, sehingga mereka bisa mengerti manfaat dari budaya barat. Dalam hal ini Soenjono mengutip karya Van Niel, The Emergence of The Modern Indonesia Elite. ${ }^{23}$ Buku Tjoerito Parasaian Me' Saleh ini juga bercerita di rentang waktu yang sama dengan era ini. Tulisan Soenjono ini terdapat dalam buku Evaluasi dan Strategi Kebudayaan yang disunting oleh Dr. Muhadjir ${ }^{24}$.

Melihat dari sejarah lahirnya buku ini, tidak bisa disangkal pengaruh-pengaruh kolonial dan bentuk penerapan politik etis didalamnya, baik dari segi latar belakang tahun terbit maupun ditelisik dari isi buku.Tahun 1915, saat buku ini mulai ditulis jugaa merupakan tahun-tahun awal tumbuhnya kesadaran literasi di kalangan masyarakat di Sumatera, khususnya pada etnis minang. ${ }^{25}$

\footnotetext{
${ }^{23}$ Van Niel, (1960), The Emergence of The Modern Indonesia Elite.Chicago: Quadrangle Books,Inc.

24 Muhadjir, (1987), Kolonialisme dan Pengembangan Bahasa Nasional, kumpulan tulisan hasil seminar budaya, Depok: Diterbitkan oleh Fakultas Sastra UI (UI. Depok :1987).

25 Hanani,Silfia, Women's Newspaper As Minangkabau Feminist Movement Against
} 
Buku yang sama, edisi berikutnya terbit tahun 1965. Judulnya sudah berganti menjadi: Riwajat Hidup Dan Perasaian Saja, Moehammad Saleh Datoek Orang Kaja Besar. Tecantum juga di halaman depan bahwa buku tersebut disusun bebas dan disadur oleh cucu beliau S.M Latif. Buku tersebut diterbitkan oleh Dana Buku Moehammad Saleh (1965).Menurut Suryadi, naskah asli buku otobiografi dalam bahasa Jawi atau lebih dikenal dengan Arab Melayutidak berhasil ditemukan. Namun dari dua naskah yang ditulis ulang olehS.M Latif kemudian melahirkanpembahasan-pembahasan

mendalam oleh dua orang peneliti.

A. Teeuw pertama sekali menyebut soal otobiografi ini dalam buku Modern Indonesian Literature, Den Haag: Martinus Nijhoff yang terbit tahun 1967 dan Tsuyoshi Kato dalam tulisan berjudul Rantau Pariaman: The World of Minangkabau Coastal Merchants in Nineteenth Century. Tulisan ini dimuat dalam Journal of Asian Studies pada tahun 1980. Selanjutnya tulisan ini bisa ditemukan juga dalam buku Indonesia dalam Kajian Sarjana Jepang: Perubahan Sosial Ekonomi abad XIX \& XX dalam berbagai aspek Nasionalisme Indonesia..

Pada tahun 2017, otobiografi Me' Saleh ini kembali mengalami elaborasi di tangan sejarawan terkemuka Sumatera Barat, Mestika Zed dengan judul Saudagar Pariaman Menerjang Ombak Membangun Maskapai.Mestika Zed kemudian juga mengubahnya dari format autobiografi menjadi biografi. Buku ini dan juga segala derivatifnya bukan ditujukan untuk kepentingan feminis atau ditulis dengan perspektif feminis. Namun bagi penulis, buku ini menarik justru karena didalamnya terdapat

Marginalization in Indonesia, http:/ /www.gjat.my/gjat122018/GJAT1220187.pdf.Diakses tanggal 12 Februari 2020. kisah-kisah tentang perempuan atau persentuhan dan atau cara pandang pengarang laki-laki terhadap perempuan.

Potret tentang perempuanyang mungkin ditulis secara tidak sengaja ini barangkalai bisa menjadi kajian yang menarik, terutama karena buku ini kemudian ditujukan buat ibunya, Haji Asiah. Artinya, secara tersirat, buku ini untuk menghargai kaum perempuan dan atau bisa jadi juga untuk pembacanya kaum perempuan. Lebih jauh lagi, buku ini ditulis dengan semangat rasa hormat dan cinta penulisnya terhadap perempuan. Namun, dibalik makna itu terungkap makna lain, pengingkaran terhadap tradisi matrilineal.

Dalam buku ini juga terlihat bagaimana perempuan ditempatkan berdasarkan pandangan laki-laki dalam masyarakat pesisir pantai yang heterogen. Rangkaian teks di dalam buku ini bisa dibaca menggunakan metode dekonstruktif terhadap nilai-nilai absolut dalam budaya matrilineal minangkabau, yang menempatkan perempuan sebagai logosentrisme. Istilah ini sering digunakan dalam proses pembacaan teks terutama ketika menggunakan pendekatan dekonstruksi ala Jacques Derrida dimana dia berupaya mengkritik semua nalar yang mengacu pada absolutism. Dalam hal ini, matrilineal dan kekuasaan perempuan di Minangkabau seolah menjadi sesuatu yang absolut, kekuasaan yang tidak terbantah.Padahal, setiap anggapan adalah kontekstual bukan sebuah makna final.Konsep dekonstruksi ini, menurut penulis, sangat mungkin diterapkan pada teks Buku Tjoerito Parasaian Me' Saleh.Tulisan ini juga berupaya mengungkap fakta-fakta tentang berbagai tradisi dalam sistem matrilineal yang diabaikan.

\section{Menelisik Isi Buku Otobiografi Me' Saleh} Sebelumnya penulis perlu mendudukkan dulu posisi buku Otobiografi Me' Saleh, dimana naskah aslinyaditulis dalam 
bentuk huruf Arab Melayu hanya dilampirkan dalam bentuk dokumentasi foto tak beberapa halaman saja. Pernyataan ini dikuatkan oleh Suryadi dalam ulasannya tentang buku karya Mestika Zed ${ }^{26}$. Untuk penulisan artikel ini, penulis menggunakan rujukan utama buku saduran pertama yang berjudul Tjoerito Parasaian Me' Saleh Gala Datoe' Rangkayo Basa oleh S.M. Latif terbitan Bandung pada tahun 1933. Dalam Bab Sapatah Kato , S.M Latif menyatakan bahwa buku itu awalnya dikarang sendiri oleh Me' Saleh dalam bahasa Melayu Riau dan bertuliskan huruf Arab kirakira tahun 1915. Karena ada kata 'kira-kira' inilah agaknya maka ada perbedaan tahun ketika Tsuyoshi Kato menyebut buku aslinya terbit tahun 1914.

Merujuk pada fakta ini dimana naskah asli tidak bisa ditemukan transkripsi yang dilakukan oleh S.M Latif bisa dikategorikan sebagai saduran atau kaba yang ditranskripsikan. Dengan demikian fakta dan data dalam buku ini tidak bisa sepenuhnya dikategorikan sebagai data sejarah namun sebagai karya sastra lisan yang ditranskripsikan. $^{27}$

Tsuyoshi Kato dan Mestika Zed telah menulis kembali buku ini sebagai sebuah karya sejarah. ${ }^{28}$ Tentu saja dua karya akademik tersebut tidak lagi masuk dalam kategori karya sastra sebagaimana naskah aslinya, karena sudah dilengkapi dengan data-data dan penelusuran sejarah. Bagaimanapun, kebenaran sejarah dan analisis historiografis semata-mata menggunakan teks dalam buku

${ }^{26}$ Suryadi, (2011), Sebuah Otobiografi dengan Interpretasi Tak

Henti.https://niadilova.wordpress.com/2018/03/11/se buah-otobiografi-dengan-interpretasi-tak-henti/

${ }^{27}$ S.M. Latif, op.cit. hal. 44-45.

${ }^{28}$ Kato, Tsuyoshi, (1986), Rantau Pariaman: The World of Minangkabau Coastal Merchants in Nineteenth Century dalam buku berjudul Kajian Sarjana Jepang: Perubahan Sosial Ekonomi abad XIX \& XX dalam berbagai aspek Nasionalisme Indonesia. Jakarta: yayasan Obor Indonesia,1986). asli tidak tepat dilakukan. Dengan alasan inilah maka hal lain yang mungkin bisa dilakukan adalah pada analisis makna teks, sebagai sebuah karya sastra.

Tidak seperti kebanyakan orang Minang terutama setelah tahun-tahun kematian Me' Saleh bahkan sampai hari ini yang sukses di perantauan, dia malah meraup sukses di kampung halamannya sendiri. Dalam buku ini diceritakan bahwa Me' Saleh, menjalani hidupnya sampai tua di Pariaman. Walaupun sebenarnya anak seorang saudagar pula, namun dia memulai hidup dengan banyak kesusahan. Ayahnya, Oerang Kajo Peto Radjo semasa hidup pernah jaya, namun kemudian jatuh miskin. Me' Saleh, melalu usahanya sendiri kemudian menjelma menjadi seorang saudagar besar. Di antara usaha yang dirintisnya adalah, berdagang karambie tjoekie (kopra), minyak manib (minyak kelapa). Kelapa dan kopra sampai hari ini masih menjadi komoditi unggulan dari Pariaman.

Selain merintis usaha di bidang kopra, Me' Saleh juga dikenal sebagai saudagar garam. Dan yang paling disebut-sebut orang adalah usahanya di bidang perkapalan. Dia memiliki berpuluh-puluh orang anak buah kapal, banyak biduk dan pincalang dan juga memiliki gudang-gudang di kawasan pasar Pariaman, untuk menampung dagangannya. ${ }^{29}$

Tidak ada disebutkan dalam buku ini kalau Me' Saleh pernah menempuh pendidikan formal. Dia hanya belajar menulis dan berhitung secara otodidak. Ayahnya Oerang Kajo Peto Radjo yang merupakan anak keturunan seorang raja dari Ringgah, Rantau Duabelas, Aceh Barat. Ibunya Tarus berasal dari Guguak Ampek Koto Bukittinggi yang diperkirakan hijrah ke Pariaman akibat Perang Padri. Sang ibu meninggal saat dia masih

${ }^{29}$ Haryanto, Bayu, (2017), Rumah Gadang Mohammad Salehg, http://www.kidalnarsis.com/ 2017/10/ mengunjungi-rumah-gadang-mohammadsaleh.html. 
sangat kecil. Porsi cerita tentang ibu dan keluarga besar ibunya ditulis sangat sedikit. Ini merupakan hal menarik jika dikaitkan dengan konteks tradisi matrilinial minangkabau, dimana ibu dan keluarga pihak ibulah yang dominan dalam kehidupan seorang anak.

Kekejaman pola asuh kakaknya Nansibah dan kemanjaan-kemanjaan yang diberikan ayahnya juga menjadi sesuatu yang bertolak belakang dari keharusan tradisi pengasuhan dalam masyarakat Minangkabau. ${ }^{30}$ Walaupun Rajabuntuk menyebut generasi minang berikutnya yang lahir setelah era Me'Saleh dalam bukunya Masa Ketjil di Kampung juga mengalami kesusahan yang sama dengan Me' Saleh, kecil-kecil ditinggal mati ibunya, namun pengasuhan Rajab tetap digambarkan di bawah pengawasan keluarga ibu dan mamaknya. ${ }^{31}$ Me'Saleh menyebutkan pengasuhannya dilakukan oleh ayahnya dengan bantuan para budak.

Hal lain dalam tradisi matrilinial yang kemudian diabaikan oleh $\mathrm{Me}$ ' Saleh dalam buku ini adalah perkara suku dan pewarisan harta pusaka. Sepanjang cerita yang ketebalannya 112 halaman, tak sekalipun disebut apa suku Me' Saleh. Padahal suku adalah sesuatu yang sangat penting dan menjadi penanda bagi keabsahan jati diri orang minangkabau.

\section{Tradisi Matrilineal Dan Pengingkarannya}

Perkembangan Islam di Pesisir Barat Sumatera, khususnya di daerah Pariaman banyak memberi pengaruh terutam berkaitan dengan tradisisistem patrilineal. Tarik menarik kekuasaan antara Kerajaan Pagaruyung dan Kesultanan Aceh yang sekian lama menguasai daerah Rantau pasisie ini meninggalkan bekas yang unik pada tradisi

${ }^{30}$ Latif, op.cit, hal 22-29.

${ }^{31}$ Radjab: Masa Ketjil Dikampung, op.cit. hal. 55 masyarakatnya. ${ }^{32}$ Walaupun belum bisa dipastikan dan butuh penelitian lanjutan, namun ada kemungkinan penghianatan Pagaruyuang dengan meminta VOC untuk turut menghentikan monopoli Aceh atas Rantau Pasisie dicatat oleh masyarakat Pariaman sebagai kelicikan. Walaupun pada akhirnya, ketika VOC berhasil mengusir Aceh dari Pesisir Sumatera Barat pada tahun 1666 dan hubungan antara pusat Kerajaan Pagaruyung dan rantau pasisie kembali erat namun itu tidak serta merta dapat mengubah tradisi unik dalam masyarakat. Mereka mengingkari Pagaruyung yang teguh dengan budaya matrilinealnya dengan mempertahankan tradisi patrilineal.Sesuai kontek waktunya, penulis melihat tiga pengingkaran tradisi matrilineal dalam laku masyarakat di Rantau Pasisie Pariaman dalam otobiografi Me' Saleh ini.

\section{Pertama: Peran ayah.}

Peran ayah dalam tradisi matrilineal sangat kecil, bahkan nyaris tidak disebutkan. Baik merujuk pada tambo maupun referensi lain yang lebih modern, seperti dalam buku Pendidikan Matrilineal yang ditulis oleh Jamaris Jamna. Peran ayah digantikan oleh tungganai (mamak rumah).Tungganai adalah anggota laki-laki tertua di rumah itu.Mamak berkewajiban mengunjungi kemenakan hampir setiap hari dan bapak dari anak-anak hanya pada malam hari. ${ }^{33}$

Di antara ciri keluarga matrilineal adalah, pertama: Keturunan dan pembentukan keluarga didasarkan pada garis ibu. Kedua, Perkawinan bersifat matrilokal, yaitu suami mengunjungi rumah istri dan tiap orang diharuskan kawin dengan orang dari luar

\footnotetext{
32 Budi Utomo, Bambang, (2011), Atlas Sejarah Indonesia Masa Islam, Jakarta: Kementrian Kebudayaan dan Pariwisata Direktorat Geografi Sejarah. hal 43

33 Jamna-Jamaris, (2004), Pendidikan Matrilinial, Padang: PPIM. hal 35.
} 
sukunya.Ketiga, anggota kelompok kerabat merasa bersaudara kandung, senasib, sehina, semalu.Keempat, ada pembagian kekuasaan antara ibu (kekuasaan hakiki) dan kekuasaan teknis pada mamak.Kelima, pusaka tinggi turun dari mamak ke kemenakan.Dengan pola seperti ini maka nilai-nilai pendidikan yang dominan diterima merupakan warisan dari anggota keluarga pihak ibu.Secara sosial dan psikologis, anak-anak juga akan dekat dengan pihak ibu. Umar Yunus, Kato, Hamka, Rajab, Taufik Abdullah dan Jamaris, semuanya menuliskan hal yang sama dengan cara pandang yang sama terhadap konsep keluarga matrilineal ini.

Dalam Otobiografi Me' Saleh, keadaan ini berlainan. Sosok ayah sangat kuat mempengaruhi cara dia berpikir dan bersikap. Gambaran tentang ayahnya yang bernama Oerang Kajo Peto Rajo (Orang Kaya Peto Raja) justru sangat kuat sehingga mengalahkan gambaran tentang ibunya. Padahal dijelaskan bahwa ayahnya keturunan Aceh dan ibunya Taroeih. "Koedian Ayah nikah "lo djo soerang padoesi namo si Taroeih." (Kemudian Ayah menikah pula dengan seorang perempuan nama si Taruih) $)^{34}$.

Sependek itu saja dia menuliskan tentang ibunya. Istri kedua ayahnya yang pada bagian lain ada disebutkannya sebagai perempuan berambut sangat panjang. Selebihnya tentang ayahnya cukup terang dan panjang.Me' Saleh dalam bukunya juga memaparkan pentingnya memilih menantu laki-laki dengan meneliti keturunannya, tidak saja soal gelar Sidi, Bagindo atau Sutan tetapi juga yang pandai berniaga. Karena ini menyangkut keuntungan yang akan di dapat.

“Santano balang bapa'nyo, koerangkoerangnyo koreang tibo di anaknyo. Ba' itoe djoeo nan bangso bodoh, bingoeng, bangso gilo atau bangso

\footnotetext{
${ }^{34}$ Latif, op.cit. hal 11
}

baga' barani.Samonyo turun dari bapa'."(Seumpama belang bapaknya, kurang-kurangnya koreng sampai di anak.Begitu juga yang bangsa bodoh, bingung, bangsa gila atau bagak berani.Semua turun dari bapa) ${ }^{35}$.

Cerita selanjutnya berkenaan dengan keluarga, dalam buku ini memang dominan oleh pertalian dari garis ayah. Bahkan dalam soal menikahkan saudara perempuannya, Me' Saleh menceritakan bagaimana ayahnya habishabisan untuk mendapatkan jodoh yang baik, keturunan raja-raja. Pernikahan yang membuat bangkrut usaha ayahnya.Tapi itu tidak dia hiraukan demi mendapatkan bibit laki-laki yang baik dan berbangsa.Hal ini mungkin juga yang menjadi akar tradisi uang jemputan di Pariaman sampai hari ini.

Pada bagian lain, ketika ayahnya mengundurkan diri dari dunia perniagaan dan pindah ke sebuah kampung bernama Piloebang, semua anak dan kedua istrinya juga turut dibawa serta ${ }^{36}$.Ini menggambarkan bagaimana posisi seorang laki-laki/suami/ ayah sangat kuat.

Kedekatan kepada ayah memang tidak menghalangi Me'Saleh untuk bergaul dengan keluarganya dari pihak ibu, namun tetap tempat menumpang yang utama adalah ayah dan kemudian kakak perempuannya. Diceritakan, setelah ayahnya kembali ke Piloebang dan dia memutuskan balik ke Pariaman maka yang ditumpanginya adalah kakak perempuannya Nangsibah bukan mamak nya (Mak Ongga) yang tinggal tak jauh dari tempat sang kakak. Ada kemungkinan, kedekatan ini juga dipengaruhi oleh sumbersumber materi yang dimiliki pihak keluarga laki-laki atau keluarga perempuan.Secara ekonomi, Mak Ongga bukan orang berada

${ }^{35}$ Ibid. hal 4

${ }^{36}$ Ibid. hal 16 
yang mampu menampung Me'Saleh.Dia hanya hidup dari berdagang di sebuah kedai kecil. Kondisi ini juga yang mungkin menjadi pertimbangan seorang anak memilih tempat malakok (menumpangkan hidup).

\section{Kedua: Kedudukan Perempuan}

Dalam tradisi masyarakat yang menganut sistem matrilineal, harta pusaka, termasuk anak keturunan baik laki-laki maupun perempuan sepenuhnya berada dalam garis silsilah perempuan. Artinya, dari nenek diwariskan kepada ibu dan dari ibu terus jatuh ke anak perempuannya. ${ }^{37}$ Dengan demikian, jika seorang perempuan meninggal dunia maka anaknya akan diasuh dan menjadi tanggungjawab keluarga ibunya, mungkin saudara laki-laki ibu (mamak) dan bisa juga saudara perempuan ibu. Pihak keluarga ayah dalam hal ini sama sekali tidak berkewajiban terhadap anak tersebut.

Perempuan dalam tradisi matrilineal khususnya yang berlaku di daerah darek digambarkan Bundo kanduang limpapeh rumah nan gadang. Ini artinya bahwa perempuan dalam tradisi matrilineal adalah seorang yang bertugas sebagai penghias, pemilih dan nyawa dalam rumah. Selain sebagai perhiasan dalam rumah, perempuan juga bertugas sebagai pemegang kunci lumbung padi atau harta pusaka, mengelolanya dan menggunakannya untuk kepentingan bersama dalam rumah gadang dan untuk kepentingan kaumnya.

Dari segi ketinggian ilmu pengetahuna serta kehalusan budi maka disebutkan bahwa perempuanlah yang menjadi sumber inspirasi(kapai tampek batanyo). Sementara kehalusan budi serta kebijaksanaannya digambarkan dengan kepemilikan pengetahuan yang dalam Tabu di bayang kato sampai, tahu

${ }^{37}$ Ibrahim Dt. Sanggoeno Dirajo, (2009), Tambo Alam Minangkabau Tatanan Adat Warisan Nenek Moyang Orang Minang terbitan, Bukittinggi: Kristal Multimedia. dikilek camin pacah, tabu di bulu gabak. bujan, tabu di riak rasah zaman, tabu di bulu persoalan). Bundo kanduang limpapeh rumah nan gadang. Amban puruak aluang bunian.Pusek jalo kumpulan tali.Ka biasan dalam nagari.Kapai tampek batanyo.Ka pulang tampek babarito.Tabu di baying kato sampai.Tabu dikilek camin pacah.Tabu di bulu gabak bujan.Tabu di riak rasah zaman. Tahu di bulu persoalan.

Perempuan dalam Masyarakat Matrilineali adalah bangsa manusia yang lemah gemulai dan dijadikan simbol untuk melindungi kekuasaan (harta benda) agar tida dikuasai oleh pihak lain.Lalu bagaimana Me' Saleh kemudian tumbuh dan besar dalam pengawasan ayahnya, setelah ibunya meninggal. Tidak berlaku tradisi matrilineal seperti yang digambarkan di atas dalam keluarga mereka? Bisa jadi ini salah satu bentuk pengingkaran lainnya dalam cerita otobiografi ini terhadap tradisi matrilineal di atas.

Secara jelas, S.M Latif menyebutkan bahwa pada masa Me' Saleh menulis buku itu perempuan belum dipandang sama sekali. “ Oerang padoesi di maso baliau moedo baloem dipandang samo, baloem amoeah disamokan io poelo." (Orang perempuan di masa beliau muda belum dipandang sama, belum mau disamakan ia pula). ${ }^{38}$

Dalam beberapa catatan sejarah disebutkan bahwa pada abad ke 17 daerah pesisir pantai barat, khususnya Pariaman dan Tiku merupakan daerah kunci untuk masuk ke daratan Minangkabau. Masyarakat pantai adalah masyarakat heterogen dari segi etnis, budaya dan agama berbeda dengan darek yang dianggab homogen dan asli. Persentuhan orang pantai yang dengan orang asing melahirkan karakteristik yang cukup berbeda dengan orang darek. Adaptasi yang didorong oleh kontak yang intensif dengan orang asing

${ }^{38}$ Ibid; hal II 
seperti Aceh, Nias, Bugis, India, Cina, Madura, Arab dan Eropa.

Beberapa bentuk dari sistem matrilineal yang berlaku di darat tidak sepenuhnya diikuti oleh orang rantau pasisie ini. Seperti pemberian gelar Sidi, Bagindo atau Sutan yang merupakan gelar turunan dari Bapak hal yang tidak dikenal di darek dan merupakan warisan bangsa Arab. Juga dalam adat perkawinan yang dikenal dengan istilah 'Jemputan'. Sesuatu yang mirip dengan kebiasaan di masyarakat India. Dalam hal membangun rumah gadang (rumah adat) mereka juga tidak punya tradisi seperti di darek, baik dari sisi arsitektur bangunan maupun sistem sosial di dalamnya.

Seperti jamaknya masyarakat pantai dengan topografi yang tidak sesubur di daratan maka berdagang adalah pilihan karir yang banyak dilakoni masyarakatnya. Dan watak pedagang yang cendrung materialistis membuat perbedaan yang lain lagi dalam watak penduduknya. Perempuan di Rantau Pasisie Pariaman daerah yang menjadi latar tempat tinggal pencerita Otobiografi ini memiliki karakter yang kuat. Hal ini seperti digambarkan seorang peneliti Belanda Boelhouwer yang dikutip Suryadi:

Ketika masyarakat darek kebanyakan sudah memakai pakaian gaya Arab- wanita bercadar, pria bersorban, berjubah putih panjang dan memelihara jenggotkarena dipaksa oleh kaum Paderi, orang Pariaman yang sudah lebih dahulu dari pada orang darek memeluk Islam justru masih berpakaian menurut adat lama mereka. Sebagaimana yang disaksikan Boelhouwer, pada masa itu kaum wanita di Pariaman tetap memiliki kebebasan dalam berpakaian menurut adat mereka. Mereka memakai anting dari tulang dengan lobang kuping yang besar (makin besar lobang itu makin bagus). Kaum wanita dari kelas tinggi memakai emas dan intan, sebuah gaya yang radikal yang- meminjam kata-kata
Boelhouwer lagi- "Tidak akan pernah dipraktekkan oleh wanita Eropa yang paling gila mode sekalipun." ${ }^{39}$

Dalam Tijdschrift voor Neederlands Indie tahun 1839 disebutkan bahwa: Di daerah-daerah pantai di antara mereka dan juga di antara wanita-wanita kelahiran bangsawan, banyak orang jahat. Banyak orang miskin mengalami penindasan, penyiksaan dan penganiayaan dari mereka; Mereka melaukan hal ini tanpa ada yang menghukumnya, karena tidak ada yang berani mengadukan mereka.Dalam buku Pemberontakan Agama di Sumatera Barat, Schrieke mengutip laporan yang ditulis Francis ini.

Cara pandang $\mathrm{Me}^{\prime}$ Saleh terhadap perempuan menarik untuk dicermati. Walaupun, seperti digambarkan oleh Latif bahwa pada masa mudanya, perempuan belum dipandang sama, namun dalam relasi keluarga terlihat penggambaran yang cukup seimbang. Kecuali perkara budak-budak perempuan dan ganasnya mulut serta prilaku perempuan bangsawan, termasuk kakaknya Nansibah.

Dalam masyarakat pantai yang heterogen - didukung karakter keluarga pedagangtradisi matrilineal tidak begitu menghalangi relasi dalam keluarga antara keluarga laki-laki dan cara pandang patrilinial dan konsep keluarga matrilineal. Nansibah, misalnya. Saudara perempuan Me'Saleh ini ketika menikah diceritakan tinggal berdekatan dengan mamak (saudara laki-laki ibu mereka). Tidak disebutkan apakah itu di tanah keluarga ibunya atau tanah milik suaminya. Namun kemudian keluarga itu pindah ke Djawi-Djawi, dibawa suaminya pindah ke rumah keluarganya. Me' Saleh yang juga ikut tinggal bersama keluarga kakak perempuannya itu kemudian belajar mengaji dengan saudara ipar kakaknya, To Ma'ie. Berlanjut kemudian

39 Ka'bati, (2007), Perempuan Ordo Ulakan, Jakarta: Jurnal Srintil edisi 17. 
tinggal bersama mertua kakaknya tersebut, Uniang Piak Gadang.

Banoe Idah istri Me' Saleh, Nansibah saudara perempuannya, Uniang Piak Gadang orang tua angkatnya, Solam dan Takai' saudara seayahnya, Tjie' Siam guru berhitungnya, atau Oeo Banso kakak angkatnya di Sibolga, adalah sederet namanama perempuan yang disebut dalam kisah Me' Saleh ini sebagai perempuan yang berkuasa dalam rumahnya. Hubungan antara suami istri coba dibangun dengan relasi yang seimbang. Laki-laki Pariaman, terutama seperti yang digambarkan Me' Saleh' tidak berlindung dibalik pusaka istrinya demikian juga sebaliknya. Mereka, ketika sudah menikah, akan membangun kerajaan sendiri dan harta pencarian bersama itu kemudian diperuntukkan untuk anak-anak keturunannya. Dengan demikian, suku tidak menjadi begitu dipermasalahkan. Selagi pencariannya ada dan banyak maka kedua pihak baik pihak istri maupun suami akan menikmati kesuksesan mereka. Dan ketika mereka sengsara, maka sengsara itu harus dihadapi berdua. Bantuan materi kaum sesuku atau kerabat dari nasab ayah atau ibu sangat sedikit dalam keluarga inti.

Beban kehidupan yang ditanggung bersama, seorang suami atau pasangan suami istri akan berpikir panjang untuk menikah lebih dari satu. Berbeda halnya dalam sistem matrilineal, dimana posisi suami hanyalah ibarat 'tamu' di rumah istrinya. Kewajiban utama soal nafkah keluarga menjadi beban 'mamak' di rumah istrinya. Mungkin ini akan dianggap menyederhanakan persoalan namun ditemukan pernyataan - pernyataan yang mengarah kepada kenyataan ini, dimana kekuasaan perempuan dan tradisi matrilineal yang berlaku mempengaruhi banyak laki-laki di Minangkabau terutama di darek kala itu bisa menikah berkali-kali.
Dimana singgah di sana beristri. Radjab, mengutip Prof. Dr. J. Prins dalam buku Adat en Islamietische Plichtenleer in Indonesia. Uitgeverij W Van Hoeve, 'sGravenhage (Derde druk) ${ }^{40}$, menyebutkan:

"Di Minangkabau yang mempunyai sistem matrilineal, ada beberapa distrik yang mempunyai angka-angka poligami yang tinggi: Di Agam tua 19\% dari laki-laki yang beristri mempunyai istri lebih dari satu. Di Maninjau 15,7\%. Di Batipuh dan Sepuluh Koto 14,3\% dan di Pariaman $13 \%$. Di Sumpur, pada waktu diadakan observasi, 45\% lakilaki beristri yang mempraktekkan poligami.".

Pariaman disebut sebagai daerah dengan tingkat poligami tinggi, tetapi tidak lebih tinggi (paling rendah) dibanding daerah lainnya di Darek.

\section{Ketiga Harta Pusaka dan Pandam Pekuburan}

Bagi masyarakat yang menganut sistem matrilineal, harta pusaka dan pandam pekuburan atau pemakaman adalah sebuah penanda, identitas dan penentu asal usul (sasok jarami) seseorang. Karena pentingnya soal pemakaman ini maka dalam tambo-tambo ia diatur secara jelas, dimana jika seorang laki-laki dari suku A meninggal di rumah anak atau istrinya dari suku B maka mayatnya wajib dikuburkan di pekuburan suku A.

Seringkali --bahkan sampai hari ini-sengketa soal mayat dimana harus dikuburkan ketika meninggal masing dijumpai dalam masyarakat di Minangkabau, khususnya di daerah rantau pasisie. Hal ini menunjukkan kuatnya tarik menarik sistem adat matrilineal dan sistem agama. Apalagi kalau pernikahannya dalam keluarga terjadi antara orang darek dan orang rantau. Mereka cenderung memperlihatkan kekuasaan dan

${ }^{40}$ Radjab, sistem, op.cit. hal 54 
tarik menarik adat kebiasaan, sehingga mayat terbujur lebih lama di atas rumah, menunggu sengketa soal pandam pekuburan itu selesai.

Demikian juga soal harta pusaka yang disebut sebagai harta selingkar kaum (barato salingka kaum) ${ }^{41}$. Dalam konsep matrilineal, harta pusaka dibagi dalam dua kategori yaitu sakodan pusako. Sako merupakan pusaka non benda (intangible assets) jatuhnya dari mamak mamak ke kemenakan. Sako sesungguhnya wujud dalam bentuk gelar-gelar yang mengacu kepada suku dan garis keturunannya. Sementara pusako merupakan harta benda yang diturunkan dari nenek ke ibu dan dari ibu ke anak perempuan. Namun ditemukan juga kasus-kasus dimana pusako jatuh dari mamak ke kemenakan. Jika seorang dengan mamak yang rajin dan kaya raya maka kemenakannya akan menjadi orang kaya juga. Tidak jadi soal, apakah anak kandung si mamak jauh lebih miskin dari keponakan. Karena anak mamak sama sekali tidak punya hak atas harta pusaka milik kaum atau suku ayahnya. Kondisi ini merupakan hasil pemaknaan terhadap harta selingkar kaum.

Dalam cerita Me' Saleh justru berlainan. Dia sangat peduli dengan anaknya dan tidak menyinggung-nyinggung soal keponakan dan harta pusaka. Namun menariknya, gelar adat sako dari kaum ibunya tetap dia pakai. Walaupun dalam buku otobiografi versi awal ini tidak diceritakan prosesi penganugrahan gelar tersebut namun jelas dia mencantumkan gelar Datoe' Oerang kajo Basa di akhir namanya, seperti tradisi yang biasa dipakaikan oleh orang di daerah darek, khususnya gelar dari persukuan Tanjuang Payobadar Nagari Guguak Tabek Sarojo, kampung asal ibunya. Namun ada juga kemungkinan gelar Rang Kayo itu dia terima

${ }^{41}$ Ibrahim Dt. Sanggoeno Dirajo, (2009), Tambo Alam Minangkabau. Bukittinggi: Kristal Multimedia, hal 87. dari ayahnya yang memang juga bergelar Rang Kayo Peto Rajo.Tetapi kuat dugaan yang pertama.

Peruntukan harta pencarian yang terkesan berat kepada anak dibanding keponakan dalam kisah hidup Me' Saleh ini mungkin disebabkan karena ayahnya bukan keturunan asli Minangkabau, sementara ibunya juga orang datang dari Guguak Tinggi Agam sehingga harta pusakonya di Pariaman tidak ada. Terkesan bahwa perantauan ini memberi jarak juga melemahkan pengaruh tatanan adat di wilayah asal terhadap keluarga-keluarga di wilayah rantau pesisir tersebut. Buktinya, Me'Saleh hanya membicarakan harta pencariannya saja dan upaya-upayanya atau ayahnya membangun 'kekuasaan' atas tangannya sendiri, bukan berdasarkan kaum atau suku. Dia tidak tinggal atau menikmati warisan apapun dari kaum ibunya bahkan juga dari ayahnya, kecuali nasihat-nasihat hidup dan gelar sako. Bahkan untuk perkara pandam pekuburan, Me' Saleh sepertinya mengabaikan tanah kaum ibunya ini, yang mungkin juga tidak dia ketahui dimana adanya.

Untuk pekuburan anak cucu dan keturunannya, Me' Saleh membeli sendiri tanah khusus yang dalam bukunya disebut sebagai: Pakoeboeran ana' tjoetjoe Datoe' Oerang Kajo Basa djo Haji Banoe 'Idah. ${ }^{42}$

\section{Simpulan}

Sistem Matrilineal yang menyandarkan garis keturunan pada nasab ibu memposisikan perempuan sebagai simbol. Dalam hal ini, bukan berarti perempuan benar-benar berkuasa, tetapi kekuasaan perempuan adalah kekuasaan simbolik. Demikian juga sebaliknya dalam tradisi patrinileal, laki-laki adalah simbol kekuasaan. Apakah dengan simbol-simbol seperti itu, secara otomatis perempuan dan laki-laki adalah penguasa dalam nasabnya

\footnotetext{
${ }^{42}$ Latif S.M, op. cit. hal 99.
} 
masing-masing? Tentu saja tidak. Relasi kuasa merupakan sesuatu yang cair dan bisa dinegosiasikan, sementara simbolik adalah strategi atau taktik dalam menjaga keberlangsungan sebuah kekuasaan yang dimunculkan melalui konstruksi sosial tertentu. Setidaknya begitulah yang tergambar dari telaahan terhadap kisah hidup Me' Saleh, dimana sosoknya hadir dengan simbol-simbol kekuasaan sendiri berupa harta kekayaan yang dia miliki sebagai seorang saudagar besar serta kemampuannya menuliskan kisah hidupnya dalam sebuah otobiografi (keunggulan pengetahuan/intelektual). Dua kekuatan yang membuat $\mathrm{Me}$ ' Saleh tak terkalahkan oleh konstruksi sosial yang membelenggu melalui sistem matrilineal dan patrilineal.

Alur kehidupan dalam cerita Otobiorafi Me' Saleh ini berjalan dinamis.Ada tahapan-tahapan perubahan yang terekam dengan baik, dari parasaian menuju kesuksesan. Kondisi sosial serta sistem nilai dalam masyarakat memberi ruang bagi manusia yang hidup di dalamnya dalam hal ini Me' Saleh sebagai bagian dari masyarakat Rantau Pasisie Pariaman untuk membuat pilihan hidup yang lebih baik.

Kalau dilihat dari jalannya cerita ini, beban-beban sosial dengan latar belakang adat tidak begitu menjadi belenggu dalam kehidupan Me' Saleh. Dinamisasi kehidupan di Pesisir Pantai juga membuat penduduknya bisa berdamai dengan pasang surutnya keadaan.Hal ini tentu berbeda jika dihadapkan dengan masyarakat di darek atau masyarakat yang selalu membawa dan mempertentangkan nilainilai adat seperti dalam tambo dengan realitas hidup, pada masa itu. Beban sebagai orang minang di darek dan orang rantau pesisir memang berbeda. Tentu saja kesimpulan ini tidak bertujuan untuk menyederhanakan persoalan dan perbedaan nalar antara masyarakat Minang Darek dan Minang Rantau Pasisie Pariaman. Diperlukan argumen dan penelitian lain untuk mendukung atau menolak kesimpulan ini.

\section{Daftar Pustaka}

Abidin, Masoed, (2004), Adat dan Syarak di Minangkabau. Padang. PPIM.

A. Efrianto, (2016), Jejak Peradaban Masa Lalu di Kota Pariaman, Jurnal Penelitian Sejarah dan Budaya, Vol 2 No 1, Juni 2016.

Akira Nagazumi (ed), Taufik Abdullah (pengantar), (1986), Kajian Sarjana Jepang: Perubahan Sosial Ekonomi abad XIX \& XX dan Berbagai Aspek Nasionalisme Indonesia, Jakarta. Yayasan Obor Indonesia.

Amran, Rusli, (1981), Sumatera Barat Hingga Plakat Panjang, Jakarta. Sinar Harapan.

Budi Utomo, Bambang, (2011), Atlas Sejarah Indonesia Masa Islam,Jakarta.Kementrian Kebudayaan dan Pariwisata Direktorat Geografi Sejarah.

Dt. Sanggoeno Dirajo,Ibrahim, (2009),Tambo Alam Minangkabau Tatanan Adat Warisan Nenek Moyang Orang Minang,Bukittinggi. Kristal Multimedia. Fadlillah, (2019), Malin Kundang Kompleks: Robobnya Kebudayaan Minangkabau. Padang. LPPM Universitas Andalas.

Hanani, Silfia, Women's Newspaper As Minangkabau Feminist Movement Against Marginalization in Indonesia. http:// www.gjat.my/gjat122018/GJAT12 2018-7.pdf, diakses tanggal 12 Februari 2020.

Haryanto, Bayu, (2017), Rumah Gadang Mohammad Saleh,http :// www.kidalnarsis.com/2017/10/mengu njungi-rumah-gadang-mohammadsaleh.html.

Jamna-Jamaris, (2004), Pendidikan Matrilinial, Padang.PPIM.

Junus, Umar, (1981), Mitos dan Komunikasi, Jakarta. Sinar Harapan.

Ka'bati. Perempuan Ordo Ulakan.Jurnal Srintil edisi 17 tahun 2009.

Kato, Tsuyoshi, (1986), Rantau Pariaman: The World of Minangkabau Coastal Merchants 
in Nineteenth Century dalam buku berjudul Kajian Sarjana Jepang: Perubahan Sosial Ekonomi abad XIX \& XX dalam berbagai aspek Nasionalisme Indonesia. Jakarta: yayasan Obor Indonesia.

Koto, Alaiddin, (1996), Pemikiran politik Persatuan Tarbiyah Islamiyah, Pekanbaru: Susqa Press

Latif,S.M, (1933), Tjoerito Parasaian Me' Saleh Gala Datoe' Oerang Kajo Basa, Bandoeng.

Meuraxa, Dada, (1974), Sejarah Kebudayaan Sumatera, Jakarta. Firma Hasmar.

Muhadjir (ed), (1987), Evaluasi dan Strategi Kebudayaan, Depok. Fakultas Sastra UI.

Nasroen, M, (1957), Dasar Filsafah Adat Minangkabau, Jakarta. Bintang Bintang.

Naim, Mochtar, (2013), Merantau Pola Migrasi Suku Minangkabau, Jakarta. Raja Grafindo Persada.

Navis,A.A, (1999), Yang Berjalan Sepanjang Jalan, Jakarta: Grasindo

Navis, Anas, (2001), Syeh Burhanuddin, Padang.

Purwanto. Bambang, (2001), Historisisme \& Kesadaran Dekonstruktif: Kajian Kritis Terhadap Historiografi Indonesiasentris. Jurnal Humaniora: Volume XIII No 1/2001

Radjab, Muhamad, (1964), Perang Paderi di Sumatera Barat, Djakarta, P.N. Balaipustaka.

Radjab, Muhamad, (1969), Sistem Kekerabatan di Minangkabau, Padang. Center for Minangkabau Studies Press.

Radjab,Muhamad, (1950), Masa Ketjil Dikampung (1913-1928) Autobiografi Seorang Anak Minangkabau, Jakarta. Penerbit Balai Puskata.

Schrieke,B.J.O, (1973), Pergolakan Agama di Sumatera Barat,Jakarta. Bratara.

Suryadi, (2004), Syair Sunur, Teks dan Konteks: 'Outobiografi' Seorang Ulama Minangkabau Abad ke-19, Padang. PPIM.

Suryadi, (2011), Sebuah Otobiografi dengan Interpretasi Tak Henti.https:// niadilova.wordpress.com/2018/03/11 /sebuah-otobiografi-denganinterpretasi-tak-henti/.
Undri, (2019), Narasi Gempa dalam Otobiografi Moehammad Saleh DatoekRangkayo Basa, Jurnal Sejarah. Vol 2 (2)

Yaswirman, (2006), Hukum Keluarga Islam, Padang.Andalas University Press.

Yazan, Sheiful (2019), Menggugat Pemahaman Tambo Minangkabau, Padang. Erka Publishing.

Zed, Mestika, (2017), Saudagar Pariaman Menerjang Ombak Membangun Maskapai, Jakarta. LP3ES.

Zuriati, (2007), Undang-Undang Minangkabau Dalam Perspektif Ulama Sufi, Padang.FS Universitas Andalas. 